\title{
Rosacea treated with rose petals: a calembour that affords intriguing results
}

\section{Piotr Brzezinski ${ }^{1}$, Lorenzo Martini ${ }^{2}$}

${ }^{1}$ Institute of Biology and Environmental Protection, Pomeranian Academy, Slupsk, Poland, ${ }^{2}$ University of Siena, Department of Pharmaceutical Biotechnologies, Via A. Moro 2, 53100 Siena, Italy

Corresponding author: Lorenzo Martini, E-mail: martinil163@libero.it

Sir,

Rosacea is a long-term skin condition that typically affects the face characterized by redness, pimples, swelling, and small and superficial dilated blood vessels [1]. Often the nose, cheeks, forehead, and chin are involved [2].

The cause of rosacea is unknow [1]. Risk factors are believed to include a family history of the condition [2]. Factors that may potentially worsen the condition include excessive heat, UV rays, excessive cold, spicy food, alcohol, menopause, psychological stress [3].

The presence of free radicals (as superoxide and hydroxyl) is utterly incontestable.

In 2007, Gallo and colleagues noticed that patients with rosacea had high levels of the antimicrobial peptide cathelicidin [4] and elevated levels of stratum corneum tryptic enzymes (SCTEs). Cathelicidin is not but a protein produced by neutrophil granulocytes after the signal evoked by inflammatory cytokines. It occurs spontaneously when the skin condition is affected by the presence of bacteria, especially Gram + .

This means that when a patient is affected by Rosacea the presence of bacteria is involved always.

Rosacea affects somewhere between one and ten percent of people. Those affected are most often 30 to 50 years old and female. Caucasians are more frequently affected. The condition was already described in The Canterbury Tales in the 1300s [1].
It is noticeable that rose petals, depending on the species of the roses, do contain polyphenols and ellagitannins, apt to reduce free radicals and acting as vasoconstrictor and for this they could be a special remedy to cure Rosacea.

Effectively, some Researchers [5] affirmed that petals of Rosa damascena showed a strong antiradical activity (with DPPH •). Thus, significant antiradical properties $\left(\mathrm{IC}_{50}\right.$ 1.33-0.08 $\mathrm{mg} \mathrm{mg}^{-1} \mathrm{DPPH} \bullet$ ) were demonstrated by these A.A. Moreover, notable antimicrobial activity against eight bacterial (i.e. Staphylococcus epidermidis, S. aureus, Bacillus subtilis, Micrococcus luteus, Escherichia coli, Klebsiella pneumoniae, Pseudomonas aeruginosa, Proteus mirabilis) and two yeast strains (Candida albicans, C. parapsilosis) was referred by the same Researchers. Total phenolic, flavonoid, phenolic acid, tannin, carotenoid and polysaccharide content in petals was determined using spectrophotometric methods.

It must be stressed that a complete approach to defeat all the problems concerning Rosacea (bacterial profile, redness, vasodilatation, SCTEs, free radicals, presence of mites as Demodex mites) is inconceivable and so we made up our mind to face the two main problems:

Inflammation, vasodilatation, microbial assault

Excess of free radicals.

In order to solve this dilemma we have selected 8 types of common roses that present different antiradical capacities and content of gallic acid (expressed in ellagitannins) and we have chosen different kinds of 
rose petals that showed the maximum FRAP value and the maximum of content of ellagitannins, to combat inflammation, vasodilatation, microbial assault and moreover the free radicals that represent the typical morphology of every type of Rosacea.

Ellagitannins act as anti-inflammatory agents, abstringent, antimicrobial as well.

In Tables 1 and 2 were the antiradical abilities and the contents of ellagitannins of the diverse roses are plotted [4].

And so we decided to use, in order to treat severe Rosacea, the following rose petals: Rosa gallica; Rosa alba; Rosa Provence.

Since they present a very high antiradical capacity and a very high percentage of gallic acid.(expressed in elagitannins).

But we have not neglected the other roses since they are necessary for treating other types of Rosacea, as we will explain in Materials and methods.

We have selected three volunteers, suffering from diverse kinds of Rosacea.

\begin{tabular}{|c|c|}
\hline Type of rose & Antiradical capacity measured by FRAP \\
\hline Rosa gallica & $1.43 \mu \mathrm{g} / \mathrm{ml}$ at the concentrations of $100 \mu \mathrm{g} / \mathrm{ml}$ \\
\hline Rosa alba & $1.72 \mu \mathrm{g} / \mathrm{ml}$ at the concentrations of $100 \mu \mathrm{g} / \mathrm{ml}$ \\
\hline Rose provence & $1.81 \mu \mathrm{g} / \mathrm{ml}$ at the concentrations of $100 \mu \mathrm{g} / \mathrm{ml}$ \\
\hline Rose portland & $0.99 \mu \mathrm{g} / \mathrm{ml}$ at the concentrations of $100 \mu \mathrm{g} / \mathrm{ml}$ \\
\hline Rose noisette & $1.02 \mu \mathrm{g} / \mathrm{ml}$ at the concentrations of $100 \mu \mathrm{g} / \mathrm{ml}$ \\
\hline Rose bourbon & $1.31 \mu \mathrm{g} / \mathrm{ml}$ at the concentrations of $100 \mu \mathrm{g} / \mathrm{ml}$ \\
\hline Rose tea & $1.40 \mu \mathrm{g} / \mathrm{ml}$ at the concentrations of $100 \mu \mathrm{g} / \mathrm{ml}$ \\
\hline Rose eglantine & $1.61 \mu \mathrm{g} / \mathrm{ml}$ at the concentrations of $100 \mu \mathrm{g} / \mathrm{ml}$ \\
\hline
\end{tabular}

Table 2: Content of ellagitannins in diverse rose petals (\% of the total polyphenols)

\begin{tabular}{lc}
\hline Type of rose & Content of ellagitannins (\% on total polyphenols) \\
\hline Rosa gallica & 67 \\
Rosa alba & 71 \\
Rosa provence & 69 \\
Rose portland & 72 \\
Rose noisette & 69 \\
Rose bourbon & 55 \\
Rose tea & 66 \\
Rose eglantine & 72 \\
\hline
\end{tabular}

- Mild Rosacea (that is represented chiefly by redness especially on forehead and cheekbones)

- Less severe Rosacea (pimples and very strong redness and couperose)

- Severe Rosacea (swelling and exaggerated vasodilatation in all the face).

We have chosen the following roses for the mild and less severe Rosacea, idest:

- Rose Portland, Noisette and Bourbon

- Rosa gallica, Rose Provence and Rose tea.

We have invited the three people to spread the rose petals onto their face for one hour/day and after to rinse with lukewarm water. The treatment lasted one week.

We stated the remission by comparing the gradation of red of the face redness, keeping on account this scale.

Granata; Terracotta; Kermes; Cherry; Pompeian red; Persian red; Dark pinkish.

In Table 3 the decrease of redness of the three volunteers is plotted, day by day, for the entire week.

All the cases, spreading rose petals on their face, at the end of the treatment show a decrease of the redness as well, and their "facies" exhibit a dark pinkish colour, that correspond to a real flesh-coloured appearance, that reveals a complete status of good health and remission of the syndrome.

Mild Rosacea is characterized by a cherry colour, that is the lightest red and anyway this colour decreases after the $4^{\text {th }}$ day to yield to dark pinkish.

Less severe Rosacea is characterized by a red more intense, but after the $4^{\text {th }}$ day the darkness of the face colour diminishes till Persian red, and at the end reach the Dark pinkish colour.

Severe Rosacea is characterized by a red Granata resembling dark brownish, and the remission is slower than in the other cases, although a final dark pinkish is reached after a week of treatment.

The usage of rose petals could be a very exceptional remedy for many cases of Rosacea.

Table 3: The decrease of redness of the three volunteers is plotted, for the entire week

\begin{tabular}{|c|c|c|c|c|c|c|c|}
\hline Case & $1^{\text {st }}$ day & $2^{\text {nd }}$ day & $3^{\text {rd }}$ day & $4^{\text {th }}$ day & $5^{\text {th }}$ day & $6^{\text {th }}$ day & $7^{\text {th }}$ day \\
\hline a & Cherry & Cherry & Pompeian red & Pompeian red & Pompeian red & Dark pinkish & Dark pinkish \\
\hline$b$ & Terracotta & Terracotta & Kermes & Persian red & Persian red & Dark pinkish & Dark pinkish \\
\hline c & Granata & Granata & Granata & Kermes & Kermes & Persian red & Dark Pinkish \\
\hline
\end{tabular}




\section{Consent}

The examination of the patient was conducted according to the Declaration of Helsinki principles.

\section{REFERENCES}

1. Tüzün Y, Wolf R, Kutlubay Z, Karakuş O, Engin B. Rosacea and rhinophyma. Clin Dermatol. 2014;32:35-46.

2. Bimbi C, Brzezinski P. Rosacea-like Tinea Faciei. Our Dermatol Online. 2016;7:78-80.

3. Sener S, Kilinc F, Akbas A, Metin A, Pektas SD, Neselioglu S, et al. Decreased arylesterase activity and increased total oxidative status in rosacea. Our Dermatol Online. 2017;8:385-8.

4. Yamasaki K, Di Nardo A, Bardan A, Murakami M, Ohtake T, Coda A, et al. Increased serine protease activity and cathelicidin promotes skin inflammation in rosacea. Nature Med. 2017;13:975-80.

5. Nowak R, Olech M, Pecio L, Oleszek W, Los R, Malm A, et al. Cytotoxic, antioxidant, antimicrobial properties and chemical composition of rose petals. J Sci Food Agric. 2014;94:560-7.

Copyright by Piotr Brzezinski, et al. This is an open access article distributed under the terms of the Creative Commons Attribution License, which permits unrestricted use, distribution, and reproduction in any medium, provided the original author and source are credited.

Source of Support: Nil, Conflict of Interest: None declared. 